\title{
Neonatal Screening for Congenital Hypothyroidism in Nicaragua: Audit of a Cord-blood Thyrotropin-based Program (2005-2015)
}

Journal of Inborn Errors

of Metabolism \& Screening 2019, Volume 7: e20190003

DOI: 10.1590/2326-4594-JIEMS-2019-0003

\author{
Aura Fúnez ${ }^{1,2}$; María Eugenia Lara3 ; Ana Cecilia Chévez'; Efrén Alí \\ Castellón'; Salvador Perán ${ }^{4}$; María Josefa Toro ${ }^{5}$; Eladio Montoya ${ }^{5}$ \\ and José Carlos Moreno²
}

\begin{abstract}
The aim of this study is to evaluate the Nicaraguan screening program for congenital hypothyroidism in terms of coverage and effectiveness of detection and confirmation of cases with the condition throughout a decade. Thyrotropin was quantified in cord-blood samples by a validated ELISA and a cut-off of $20 \mathrm{mU} / \mathrm{l}$ was applied. Coverage, positive predictive value, recall rate and prevalence were retrospectively analysed. Babies with positive screening results were contacted for confirmation by means of determination of thyrotropin and thyroid profile in serum samples. 272,338 babies were screened during the period 2005-2015. The mean coverage reached by the program in the participating departments was $71 \%$, with a positive predictive value of $83 \%$ and a recall rate of $0.055 \%$. Eighty cases of congenital hypothyroidism were identified, representing an incidence of 1 in 3229 live births, most of them (81\%) being severe. The performance of the Nicaraguan screening program is comparable to those in Latin America also using cord-blood samples. The incidence of congenital hypothyroidism is within the low range of other countries worldwide. Strategies are needed to expand the program to the whole country, improve recall rates and achieve earlier treatment of babies, with the condition.
\end{abstract}

\section{Keywords}

Congenital hypothyroidism, newborn, screening, cord-blood, TSH, Nicaragua.

\section{Introduction}

Congenital hypothyroidism $(\mathrm{CH})$ is the most common cause of preventable mental retardation. With the introduction of $\mathrm{CH}$ neonatal screening programs, babies affected with this condition are detected before the clinical manifestations are evident and irreversible. $\mathrm{CH}$ screening enables timely replacement with thyroxin and efficiently reduces the risk for cognitive defects [1-3].

In Latin America the first pilot neonatal screening program for CH started in Argentina in 1985, while the first nation-wide established program for $\mathrm{CH}$ was implemented in Cuba in 1986. $\mathrm{CH}$ screening programs expanded from 1985 to 2005 and reached fourteen countries of Central and South America. However, mass screening programs in Guatemala, Haiti, Honduras, El Salvador and Belize have not yet been formally implemented. [4,5] Out of 14 countries studied, only four (Cuba[6], Costa Rica[7],

\footnotetext{
${ }^{1}$ Laboratorio de Bioanálisis Clínicos, Departamento de Ciencias Fisiológicas, Facultad de Ciencias Médicas, Universidad Nacional Autónoma de Nicaragua, León, Nicaragua.

2 Thyroid Molecular Laboratory, Institute for Medical and Molecular Genetics, Hospital Universitario La Paz, Universidad Autónoma de Madrid, Madrid, Spain. ${ }^{3}$ Departamento de Ciencias Morfológicas, Facultad de Ciencias Médicas, Universidad Nacional Autónoma de Nicaragua, León, Nicaragua.

${ }^{4}$ Laboratorio de Hormonas, Hospital Universitario Carlos Haya, Málaga, Spain. ${ }^{5}$ Departamento de Biología de Sistemas, Facultad de Medicina, Universidad de Alcalá, Alcalá de Henares, Madrid, Spain.
}

Received March 20, 2019, and in revised form June 11, 2019. Accepted for publication July 22, 2019.

\section{Corresponding Author:}

José C. Moreno, MD, PhD, Thyroid molecular laboratory, Institute for Medical and Molecular Genetics (INGEMM), Hospital Universitario La Paz, Paseo de La Castellana 261, 28046 Madrid. Spain.

Email: josecarlos.moreno@salud.madrid.org 
Uruguay [8] and Chile[9]) reached a coverage close to $100 \%$. The rest had widely varying coverage rates between $1-80 \%[4]$. However, most countries have increased their coverages over $70 \%$ in the last decade.[5,10-14]

The reported incidence of $\mathrm{CH}$ in Latin America ranges from 1 in 1715 newborns (a local program in Guatemala) to 1 in 3616 (Cuban nation-wide program)[4]. These discrepancies may be influenced among others by specific characteristics of the different programs (local versus national), heterogeneity of coverages reached in the different countries, program strategy (cord-blood versus heel blood after $24 \mathrm{~h}$ ), socioeconomic status of the region and the improved sensitivity of TSH immunoassays. This has allowed many programs around the world to reduce the TSH cut-offs, making possible the identification or cases that otherwise would have been missed, therefore increasing the incidence of congenital hypothyroidism detected by these programs.[15-20]

In 2005, a pilot screening program for $\mathrm{CH}$ started in the Department of León, Nicaragua, as result of an international collaborative initiative. In ten years, the program expanded to reach more than the $50 \%$ of the national territory.

\section{Objective}

The aim of this study is to evaluate the Nicaraguan screening program for congenital hypothyroidism in terms of coverage and effectiveness of detection and confirmation of cases with the condition throughout a decade.

\section{Patients and Methods}

\section{Screening Program Design}

The CH screening program began in the department of León, within the frame of the Program of Cooperation between the University of Alcala and the UNAN-León, with the subsequent incorporation of different institutions from Spain (see authors' affiliations). Although the program was initially implemented in the University Hospital (HEODRA), from 2005 to 2015 nine additional departments gradually joined the screening effort, involving a maximum of 12 hospitals (Fig. 1).

Samples were collected in hospitals and other healthcare institutions for onward shipment to the centralized laboratory. Personal and clinical data from the mothers and their babies were recorded in a printed form.

\section{Hormone Determinations}

Thyrotropin (TSH) in dried blood spots. Immediately after delivery blood samples from the umbilical cord were collected and placed on Whatman 903 (Schleicher \& Schuell, USA) or TFN filter paper (Muntkell, Sweden) as three circular spots. An immune-enzymatic sandwich assay (ELISA) was used for the quantification of neonatal TSH. Basically, 96-well plates

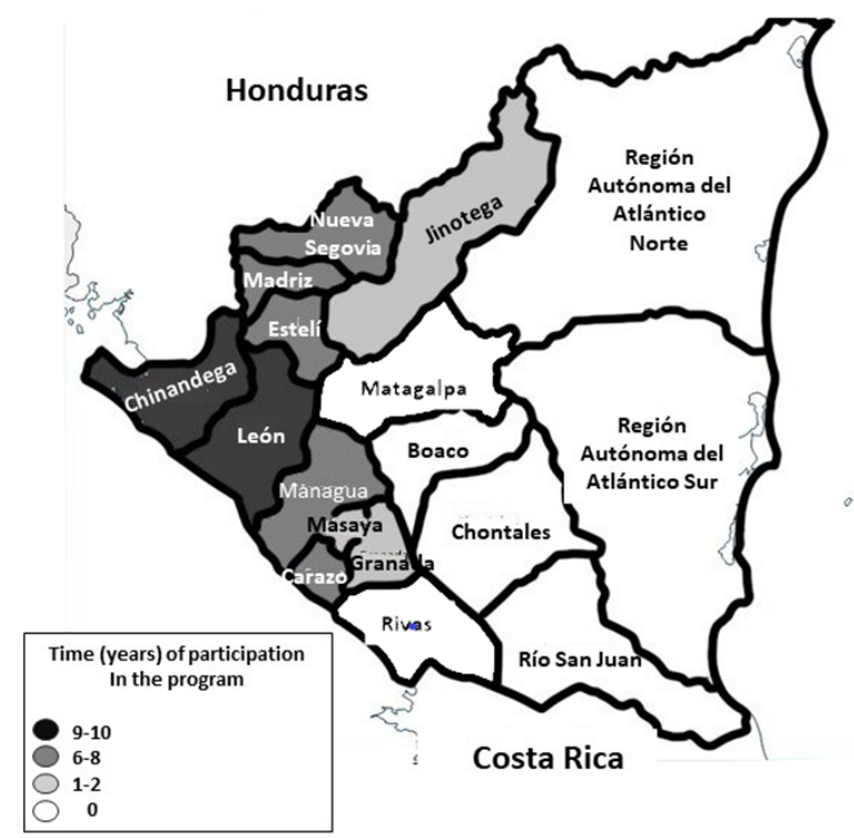

Figure 1. Time of participation of the Nicaraguan Departments in the Newborn Screening Program for $\mathrm{CH}$. The national map reflects in shades of light grey, dark grey and black the 10 provinces departments (out of 17 in the country) which participated in the program at any time between 2005 and 2015.

(Bio-one high binding, Greiner) were coated with $100 \mu \mathrm{l} /$ well of a monoclonal anti-TSH antibody $(3 \mu \mathrm{g} / \mathrm{ml}$ in Tris-buffered saline, TBS) and incubated for 60 minutes at $37^{\circ} \mathrm{C}$. This antibody recognises an epitope of the TSH- $\beta$ subunit. After washing five times with TBS-containing 0.05\% Tween (TBST) using DELFIA WASHER Disk remove (Perkin Elmer), non-specific binding was blocked by adding to each well $200 \mu \mathrm{l}$ of TBST containing $0.5 \%$ bovine serum albumin (Sigma Aldrich). Three-millimeter diameter circles of cards containing dry standards and controls (Auto DELFIA kit of neonatal human TSH dry blood, Perkin Elmer, USA) and cord-blood samples were punched with the aid of a DBS puncher, (DELFIA Dried Blood Spot Puncher, Perkin Elmer, USA) and two of these circles were used per well. Plates were incubated 60 minutes at $37^{\circ} \mathrm{C}$ in $200 \mu \mathrm{TBST}$-BSA per well with mild agitation. After overnight incubation at $4^{\circ} \mathrm{C}$ and 60 minutes at $37^{\circ} \mathrm{C}$ with mild agitation they were washed with TBST five times and $100 \mu \mathrm{l}$ of a mixture $1 / 1$ of two biotinylated antibodies directed respectively against the $\alpha$ - and $\beta$-subunits of the hormone $(0.5 \mu \mathrm{g} / \mathrm{ml})$ were added and incubated for an additional hour at $37^{\circ} \mathrm{C}$.

All the antibodies were generated in the Department of Immunology and Oncology at the Centro Nacional de Biotecnología (CNB-CSIC, Madrid, Spain). They were obtained by immunization with the whole hormone-dimer and they are TSH-specific (mean $0.1 \%$ cross-reactivity with LH, HCG and FSH).[21]

After washing, $100 \mu \mathrm{l}$ of Streptavidin-Peroxidase Polymer Ultrasensitive (Sigma-Aldrich) diluted 1 to 16,000 in TBST 
were added and plates were incubated for $1 \mathrm{~h}$ at $37^{\circ} \mathrm{C}$. Plates were washed thereafter and $100 \mu \mathrm{l}$ o-phenylenediamine dihydrochloride (Sigma Fast OPD, Sigma-Aldrich) were then added, and incubated for $30 \mathrm{~min}$. in the dark to develop colour. Reaction was stopped by the addition of $50 \mu \mathrm{l} 3 \mathrm{~N}$ sulfuric acid. Absorbance at $405 \mathrm{~nm}$ was measured in a Multiskan FC microplate reader (Thermo Fisher Scientific, USA). The TSH concentration in samples was calculated automatically with internal software by means of calibration curves built with the calibrators ran in every 96 well assay. The standard curve had a dynamic range for TSH measurement between 0.7-234 $\mathrm{mU} / \mathrm{l}$. Detection and quantification limits were 1.5 and $5 \mathrm{mU} / \mathrm{l}$, respectively. Intra- and inter-assay variations were 12 and 13\%, respectively.

Serum hormones - TSH, total thyroxine (T4) and triiodothyronine (T3) - were measured using ELISA commercial kits from Human Diagnostics, Germany.

\section{Decision Flow-chart}

A general flowchart for screening and confirmation of $\mathrm{CH}$ cases is shown in Fig. 2. A cut-off value of $20 \mathrm{mU} / \mathrm{l} \mathrm{TSH}$ was chosen to consider a sample positive, a threshold frequently used in programs using cord-blood samples.[6,22-24] Since a range of cut-offs from 15 to $40 \mathrm{mU} / \mathrm{l}$ TSH have been used by different programs and countries $[3,8,24,25]$, a trial was conducted from 2009 to 2013 to define the most efficient threshold for our conditions by lowering the cut-off to $10 \mathrm{mU} / \mathrm{l}$.

Parameters used for the confirmation of $\mathrm{CH}$ were: serum TSH values above 20 or $10 \mathrm{mU} / \mathrm{l}$ as stated above and/or T4 lower than $6.9 \mu \mathrm{g} / \mathrm{dl}$.[26-29]. Therefore, with these hormonal limits, hyperthyrotropinemia (HT) cases were initially considered as $\mathrm{CHs}$, and when the serum results were within normal values children were considered as false positive (FP).

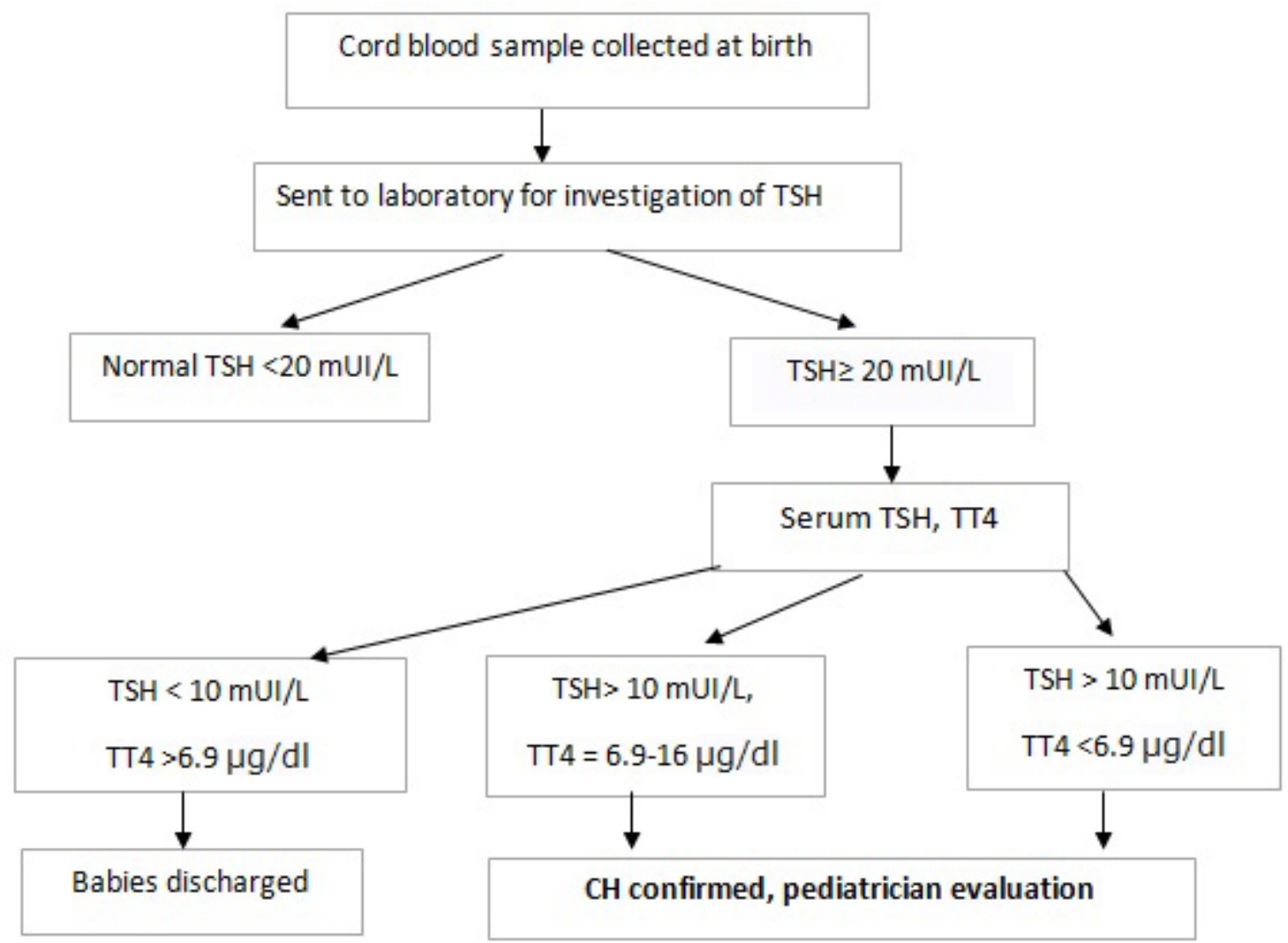

Figure 2. Flowchart for Screening of Congenital Hypothyroidism. The diagnostic of congenital hypothyroidism begins with either abnormal newborn screening test result, leading to serum thyroid function test (TSH and TT4) to confirm the diagnostic. Other diagnostic studies can be undertaken to determine the underlying etiology. 
In each hospital, an appointed paediatrician in charge of $\mathrm{CH}$ patients started levothyroxine replacement and the clinical follow-up of the patients.

A database was created for registration of samples and screening results.

\section{Classification of $\mathrm{CH}$ Severity}

We followed the criteria of the European Society for Paediatric Endocrinology (ESPE)[30] based on serum T4 levels at confirmation lower than $40 \mathrm{nmol} / \mathrm{l}(3.13 \mu \mathrm{g} / \mathrm{dl})$ to consider $\mathrm{CH}$ as severe.

\section{Performance Analysis of the Nicaraguan CH Screening Program}

The coverage of the program was determined by the ratio between the total number of screened babies and the total number of live births in each of the participating departments, for which national databases of the Nicaraguan Ministry of Health were consulted (www.minsa.gob.ni, www.inide.gob. ni). The incidence of $\mathrm{CH}$ was calculated as the ratio between the number of confirmed $\mathrm{CH}$ cases and the total number of newborns screened. The positive predictive value (PPV) for the program was calculated as the true positive (confirmed) $\mathrm{CH}$ patients divided by the total number of children retested for confirmation. Both the PPV and the false positive rate (FPR) evaluate the efficiency of mass screening program.

\section{Statistical Analysis.}

The data were processed using Microsoft Excel for Windows 10. Significance was defined at $\mathrm{p}<0.05$.

\section{Results}

Coverage and positive predictive value of the program and incidence of $\mathrm{CH}$ in Nicaragua.

The demographic characteristics of the population covered by the Nicaraguan neonatal screening program for $\mathrm{CH}$ and the results of the program are summarized in Table 1. In its first year the program covered only the department of León. Subsequently, other departments, mainly on the Pacific Coast and Central regions, the most densely populated areas, joined the program (Fig 1).

272,338 infants were screened for $\mathrm{CH}$ in 10 years, representing an average coverage of $71 \%$ of life births in the participating departments (Table 1). The coverage in the participating departments gradually increased from the initial $55 \%$ to a maximum of $87 \%$ at its best performance. However, when the total number of children born in the country is considered, only $18 \%$ benefited from screening during 2005-2015.

In the study period, 153 children were positive (TSH in cord blood $\geq 20 \mathrm{mU} / \mathrm{l}$ ), representing an average $0.06 \%$ of all samples analysed (samples received minus inadequate ones). Such percentage of positive children progressively decreased from $0.3 \%$ to $0.04 \%$ in those years in which more than 25,000 samples were analysed (Table 1).

Inadequately collected blood samples, unsuitable for TSH determination, accounted for a $5.9 \%$ in average. Experience gained in blood sampling lead to a decrease from the initial $12.5 \%$ to the $2.3 \%$ more recently (Table 1 ).

All the positive children at screening (153) were called for retesting representing an average rate of $0.055 \%$, a value in accord with international standards for TSH based screenings.[31] From these babies only 96 were retested for confirmation of the condition, giving a mean recall success rate of $68 \%$, as defined by the percentage of children that underwent retesting versus those positive at screening.

Finally, 80 out of 96 children retested were confirmed for $\mathrm{CH}$ or HT, showing decreased total T4 and elevated TSH or isolated TSH elevation, respectively (Table 1). These data indicate an estimated incidence of $\mathrm{CH}$ in Nicaragua of 1 in 3229 live births, a figure in accordance with $\mathrm{CH}$ incidence in other Latin American countries, a PPV of $83 \%$ and a relatively low FP $(16 / 96,17 \%)$ (Table 1$)$. This relatively low incidence of $\mathrm{CH}$ may be influenced by the low rate of children brought to the laboratory to be retested, since the estimation is based on the children who were actually retested.

\section{Sensitivity of the screening program for moderate $\mathrm{CH}$ cases}

In $\mathrm{CH}$ screening programs based on the analysis of cord-blood samples are obtained when TSH is physiologically increased. $[3,29,32]$ This implies a limitation to establish the most efficient cut-off TSH level, balancing the highest $\mathrm{CH}$ identification rate possible without the cost of excessive FP.[6]

To investigate the sensitivity of the Nicaraguan program towards cases of moderate hypothyroidism, including HT, we categorized the positive children at screening in three groups: those ranging from 20 to $39 \mathrm{mU} / \mathrm{l} \mathrm{TSH}$, those with TSH between 40-100 mU/l and those exceeding $100 \mathrm{mU} / 1 \mathrm{TSH}$ (Table 2). Then, we retrospectively analysed the percentage of children confirmed with serum hormone tests as $\mathrm{CH}$ (elevated TSH, low T4), HT (elevated TSH, normal T4) or FP (normal TSH and T4) in each category (Table 2). From 96 children retested in serum, $71 \%$ had $\mathrm{CH}, 13 \%$ showed HT and $17 \%$ were FP (Table 2). Most babies retested (95\%) had shown cord-blood TSH levels higher than 40 $\mathrm{mU} / \mathrm{l}$, while only $29 \%$ of those with screening TSH of 20-39 kept their appointments for serum retesting (Fig. 3), concentrating the lowest recall rate in the series.

Twelve babies with congenital HT were detected by the program (Table 2). Most HT cases (68\%) were found from the group with cord-blood TSH levels between 20-39 mU/l, but not exclusively. Four cases with HT were detected with cord-blood TSHs levels above $40 \mathrm{mU} / \mathrm{l}$. Remarkably, one case with very 
Table 1. Characteristics and results of the neonatal screening for $\mathrm{CH}$ in Nicaragua over a period of 10 years (2005-2015). ${ }^{1}$ Number of Nicaraguan Departments participating in the screening program per year. ${ }^{2}$ Inadequate samples for TSH determination due to faulty technique in cord-blood sample collection. ${ }^{3}$ The percentage of children retested in serum for $\mathrm{CH}$ confirmation does not consider children who died before serum confirmation test. ${ }^{4}$ Children deceased before recall for serum confirmation of $\mathrm{CH}$.

\begin{tabular}{|c|c|c|c|c|c|c|c|c|c|c|c|c|}
\hline Year & 2005 & 2006 & 2007 & 2008 & 2009 & 2010 & 2011 & 2012 & 2013 & 2014 & 2015 & $\begin{array}{c}\text { Total } \\
\text { (average) }\end{array}$ \\
\hline $\begin{array}{l}\text { DEMOGRAPHY } \\
\text { Deparments' }^{1}\end{array}$ & 1 & 3 & 5 & 9 & 10 & 10 & 9 & 6 & 6 & 6 & 6 & 6.5 \\
\hline Live births & 3.761 & 7.876 & 21.287 & 43.310 & 48.311 & 44.383 & 49.844 & 44.093 & 38.990 & 40.713 & 40.085 & 382.653 \\
\hline $\begin{array}{l}\text { Screened } \\
\text { Children }\end{array}$ & 2.081 & 4.761 & 14.822 & 29.455 & 39.305 & 38.791 & 33.939 & 30.833 & 25.931 & 26.495 & 25.925 & 272,338 \\
\hline Coverage (\%) & (55) & $(60)$ & (70) & $(68)$ & (81) & (87) & (68) & (70) & (67) & (65) & (65) & (71) \\
\hline $\begin{array}{l}\text { SCREENING } \\
\text { Positive children }\end{array}$ & 4 & 13 & 8 & 13 & 21 & 17 & 12 & 12 & 21 & 21 & 11 & 153 \\
\hline $\begin{array}{l}\text { Positive children } \\
\text { (\%) }\end{array}$ & $(0.2)$ & $(0.3)$ & $(0.1)$ & $(0.04)$ & $(0.1)$ & $(0.04)$ & $(0.04)$ & $(0.04)$ & $(0.1)$ & $(0.1)$ & $(0.04)$ & $(0.06)$ \\
\hline $\begin{array}{l}\text { Inadequate } \\
\text { samples }^{2}\end{array}$ & 261 & 269 & 1312 & 2.076 & 2.357 & 2.078 & 937 & 1.367 & 795 & 620 & 1.925 & 13997 \\
\hline $\begin{array}{l}\text { Inadequate } \\
\text { samples (\%) }\end{array}$ & 12.5 & 5.7 & 8.8 & 7 & 5.9 & 5.4 & 2.8 & 4.4 & 3.1 & 2.3 & 7.4 & (5.9) \\
\hline $\begin{array}{l}\text { CONFIRMATION } \\
\text { Retested } \\
\text { Children }\end{array}$ & 3 & 7 & 6 & 8 & 9 & 12 & 6 & 5 & 15 & 16 & 9 & 96 \\
\hline $\begin{array}{l}\text { Recall success } \\
\text { rate }(\%)^{3}\end{array}$ & (75) & (54) & (86) & $(62)$ & (45) & (75) & (75) & $(45)$ & (83) & (76) & (90) & (68) \\
\hline $\begin{array}{l}\text { Deceased } \\
\text { Children }^{4}\end{array}$ & - & - & 1 & - & 1 & 1 & 4 & 1 & 3 & - & 1 & 12 \\
\hline Children with HC & 3 & 7 & 6 & 8 & 7 & 9 & 5 & 3 & 12 & 14 & 6 & 80 \\
\hline False positives & - & - & - & - & 2 & 3 & 1 & 2 & 3 & 2 & 3 & 16 \\
\hline False positives (\%) & - & - & - & - & 22 & 25 & 16 & 40 & 20 & 12.5 & 33 & $(16.9)$ \\
\hline
\end{tabular}

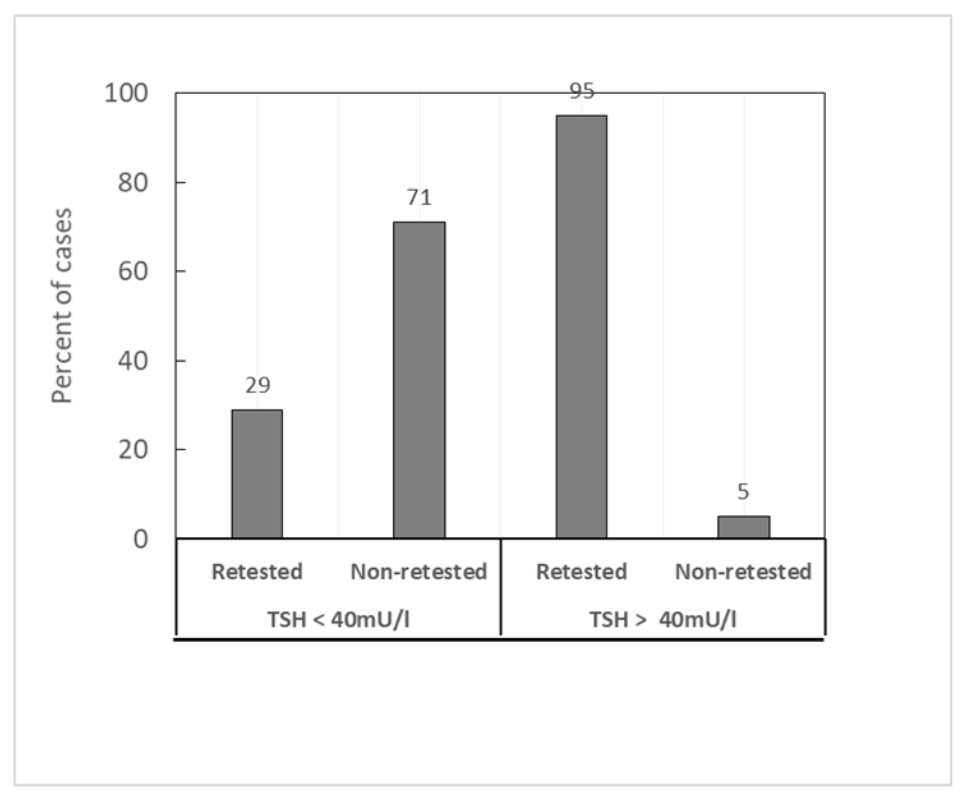

Figure 3. Percentages of retested and non-retested children who were positive at $\mathrm{CH}$ screening, considering their cord-blood TSH level (less than $40 \mathrm{mu} / \mathrm{L}$ or above $40 \mathrm{mU} / \mathrm{l})$. 
Table 2. Thyroid hormone profile of neonates positive at the $\mathrm{CH}$ screening, categorized in 3 groups depending on cordblood TSH levels: 20-40, 40-100 and >100 $\mathbf{~ m U / I , ~ r e s p e c t i v e l y . ~} \mathrm{CH}$, congenital hypothyroidism; HT, hyperthyrotropinemia; FP, false positive; cbTSH, TSH from cord blood (eluate from filter-paper spots); sTSH: serum TSH at recall; T4, serum total thyroxine at recall; T3, serum total tri-iodothyronine at recall. M mean; SD, standard deviation; n, number of individuals. For reference ranges of serum TSH, T4 and T3 (see references 26-29). Reference ranges for sTSH: < $10 \mathrm{mU} / \mathrm{l}$ (Hubner et al 2002; Djemli et al., 2004; Kapelari et al., 2008, Rastogi \& LaFranchi 2010), and <7 mU/l between 1-12 months of life (Hubner et al 2002; Djemli et al., 2004; Kapelari et al., 2008) for T4: 6.9-16 $\mu \mathrm{g} / \mathrm{dl}$ (Rastogi \& LaFranchi, 2010) and for T3: 0.9-2.4 ng/ml (Djemli et al 2004).

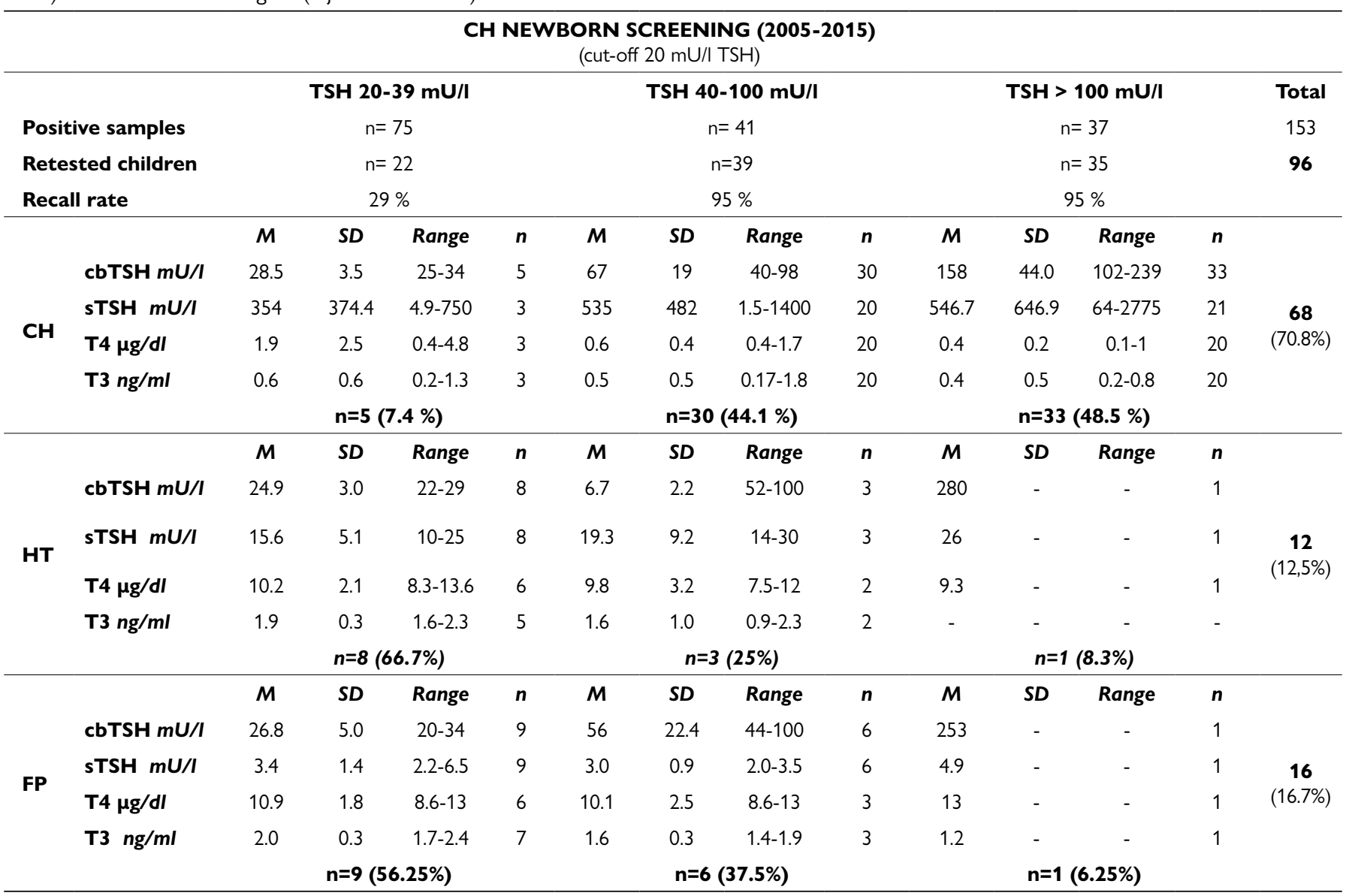

high cord-blood TSH $(280 \mathrm{mU} / \mathrm{l})$ evolved into mild euthyroid $\mathrm{HT}(\mathrm{TSH}=26 \mathrm{mU} / \mathrm{l}$ and $\mathrm{T} 4=9.3 \mu \mathrm{g} / \mathrm{dl}$ in serum) (Table 2$)$.

Most FP cases showed neonatal TSH lower than $40 \mathrm{mU} / \mathrm{l}$ (56\%), but a substantial $37 \%$ had cord-blood TSH above $40 \mathrm{mU} / \mathrm{l}$.

According to ESPE criteria for categorization of $\mathrm{CH}$ severity (see Methods), the vast majority of patients (81\%) detected by the Nicaraguan screening program are severely hypothyroid. Indeed, the correlation study between the cord-blood or serum TSHs values and the serum T4 shows that, for a wide range of TSH levels, many positive children with $\mathrm{CH}$ had nearly undetectable T4 with a significantly higher correlation with serum than cordblood TSH ( Fig. 4 A, C). In the case of T3, almost undetectable values were also present, with a significant correlation similar with both serum and cord-blood TSH (Fig. 4 B, D), although the low values of T4 and T3 could also be influenced by the excessive time elapsed between positivity at screening and serum hormone retesting.

In an attempt to increase the detection rate for moderate/ mild cases of hypothyroidism, a four-year trial (2009-2013) was implemented by lowering the cut-off TSH value to $10 \mathrm{mU} / \mathrm{l}$. Table 3 shows the results of this trial, comparing the percentage of children with $\mathrm{CH}$ and $\mathrm{HT}$ and the FP identified within 3 different group of babies having, respectively, TSH cord-blood levels of 10$19,20-40$ and above $40 \mathrm{mU} / 1 \mathrm{TSH}$ at screening. Babies screened with neonatal TSH of 10-20 mU/l, were all FP cases (Table 3). Therefore, lowering the cut-off TSH from 20 to $10 \mathrm{mU} / \mathrm{l} \mathrm{TSH}$ did not improve the detection rate of patients with neither $\mathrm{CH}$ nor HT, while worsening the PPV of the program from $83 \%$ to $62.5 \%$. These results indicate that the initially used cut-off of $20 \mathrm{mU} / \mathrm{l}$ is the most convenient threshold for the cord-blood 
A
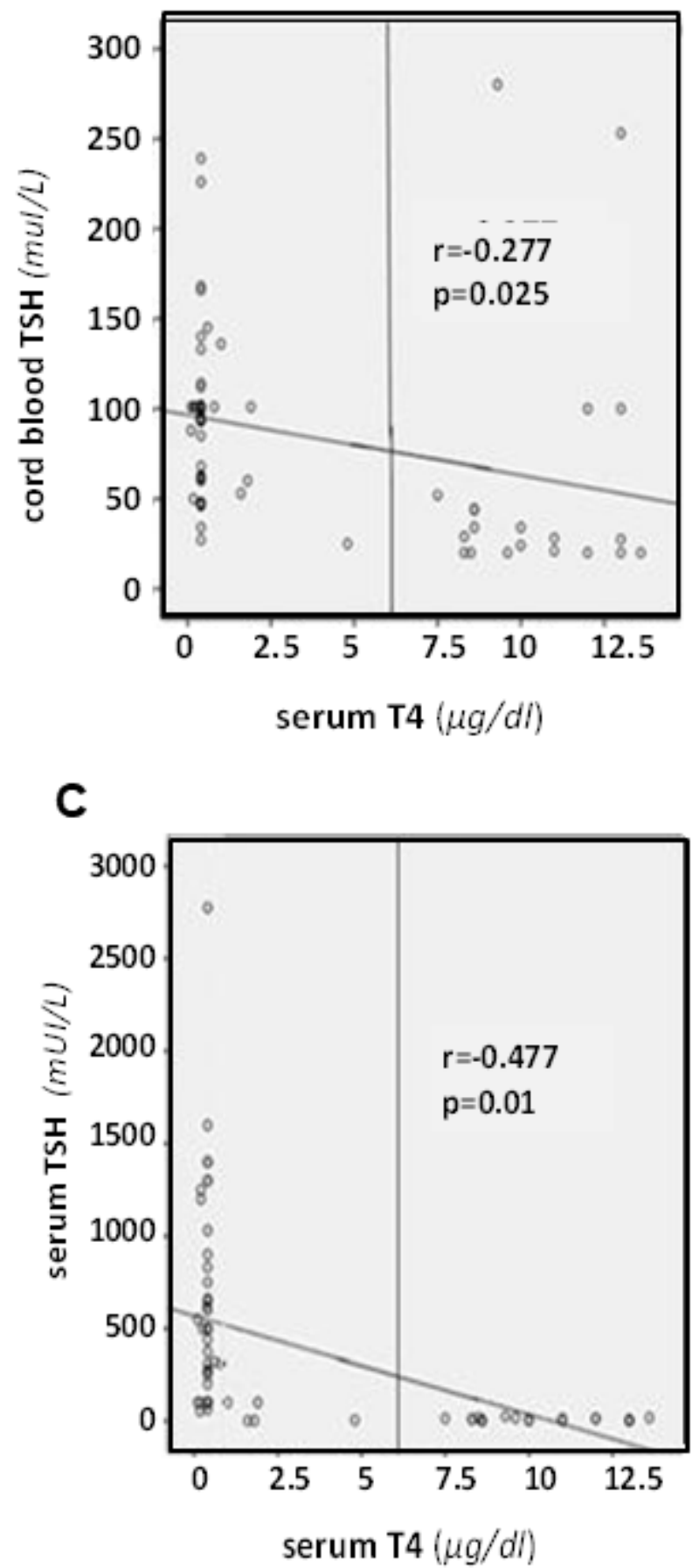
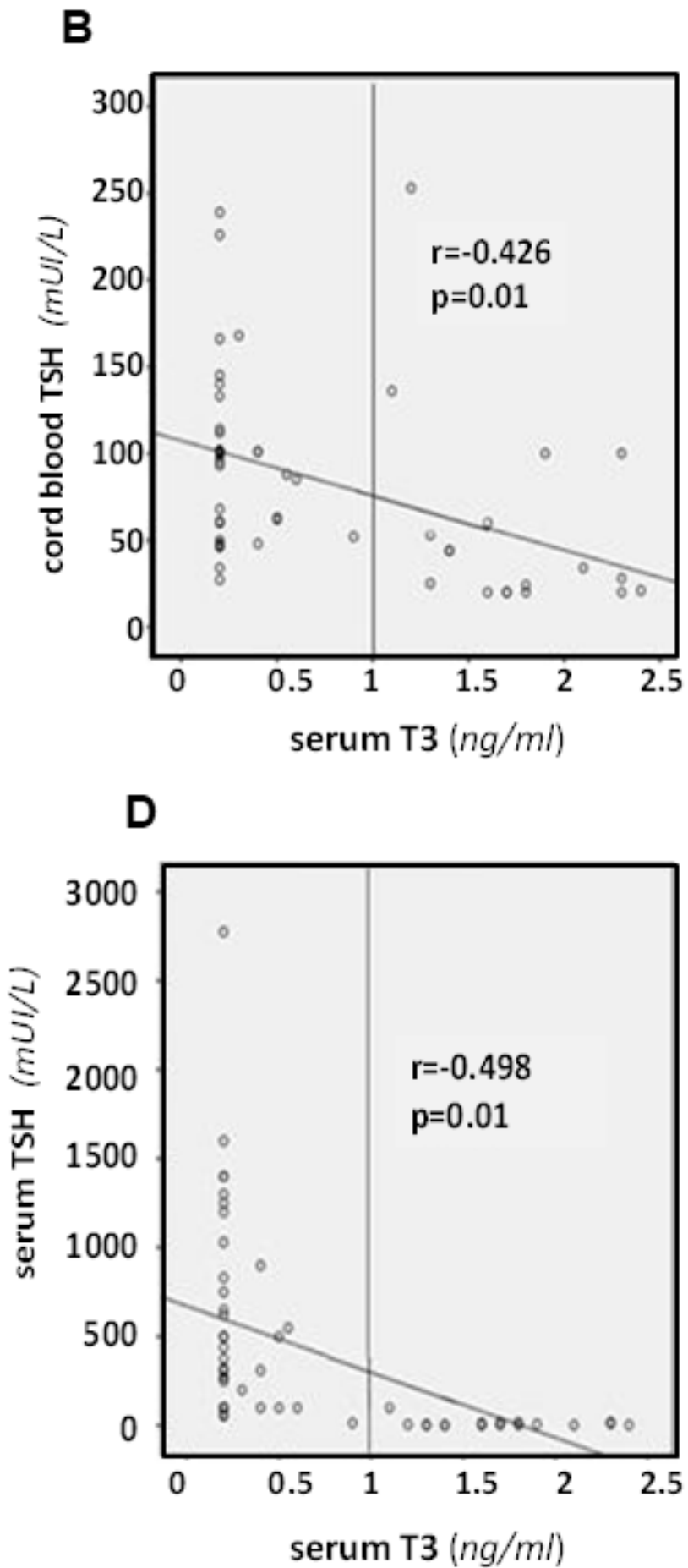

Figure 4. Correlations between cord blood TSH at $\mathrm{CH}$ screening, or serum $\mathrm{TSH}$ at $\mathrm{CH}$ confirmation and thyroid hormones, $\mathrm{T} 4$ or $\mathrm{T} 3$ at $\mathrm{CH}$ confirmation. A. Correlation between cord blood TSH and serum T4 $(\mathrm{p}=0.025, r=-0.277)$ B. Correlation between cord blood TSH and serum T3 $(p=0.01, r=-0.426)$. C. Correlation between serum TSH and T4 ( $p=0.01, r=-0.477)$. D. Correlation between serum TSH and T3 $(p=0.01, r=-0.498)$. 
Table 3. Thyroid hormone profile of positive children at the Nicaraguan $\mathrm{CH}$ screening trial (2009-2013) categorized in 3 groups depending on cord blood TSH levels: 10-20, 20-40 and >40 $\mathbf{m U / l}$, respectively. $\mathrm{CH}$, congenital hypothyroidism; $\mathrm{HT}$, hyperthyrotropinemia; FP, false positives. cbTSH, TSH from cord blood (eluate from filter-paper spots); sTSH: serum TSH at recall; T4, serum total thyroxine at recall; T3, serum total tri-iodothyronine at recall. M, mean; SD, standard deviation; n, number of individuals. For reference ranges of serum TSH, T4 and T3 (see references 26-29). Reference ranges for sTSH: < $10 \mathrm{mU/l}$ (Hubner et al 2002; Djemli et al., 2004; Kapelari et al., 2008, Rastogi \& LaFranchi 2010), and <7 mU/l between 1-12 months of life (Hubner et al 2002; Djemli et al., 2004; Kapelari et al., 2008) for T4: 6.9-16 $\mu \mathrm{g} / \mathrm{dl}$ (Rastogi \& LaFranchi , 2010) and for T3: 0.9-2.4 ng/ml (Djemli et al 2004).

\begin{tabular}{|c|c|c|c|c|c|c|c|c|c|c|c|c|c|c|}
\hline \multicolumn{15}{|c|}{$\begin{array}{l}\text { CH NEWBORN SCRRENING TRIAL (2009-2013) } \\
\text { (cut-off point } 10 \mathrm{mU} / \mathrm{l})\end{array}$} \\
\hline & & \multicolumn{4}{|c|}{ TSH $10-20 \mathrm{mU} / \mathrm{I}$} & \multicolumn{4}{|c|}{ TSH $20-40 \mathrm{mU} / \mathrm{I}$} & \multicolumn{4}{|c|}{$\mathrm{TSH}>\mathbf{4 0} \mathrm{mU} / \mathrm{l}$} & Total \\
\hline \multicolumn{2}{|c|}{ Positive samples } & \multicolumn{4}{|c|}{115} & \multicolumn{4}{|c|}{38} & \multicolumn{4}{|c|}{40} & 193 \\
\hline \multicolumn{2}{|c|}{ Retested children } & \multicolumn{4}{|c|}{32} & \multicolumn{4}{|c|}{17} & \multicolumn{4}{|c|}{37} & 86 \\
\hline \multicolumn{2}{|c|}{ Recall rate } & \multicolumn{4}{|c|}{$27.8 \%$} & \multicolumn{4}{|c|}{$44.5 \%$} & \multicolumn{4}{|c|}{$92.5 \%$} & \\
\hline \multirow{5}{*}{$\mathbf{C H}$} & & $M$ & $S D$ & Range & $n$ & $M$ & $S D$ & Range & $n$ & $M$ & $S D$ & Range & $n$ & \\
\hline & sTSH $m U / I$ & - & - & - & - & 299.5 & 321 & $50-750$ & 4 & 286.9 & 333.8 & $54-1400$ & 32 & 36 \\
\hline & T4 $\mu \mathrm{g} / \mathrm{dl}$ & - & - & - & - & 0.4 & - & 0.4 & 2 & 0.4 & 0.2 & $0.1-1.0$ & 22 & \\
\hline & $\mathrm{T} 3 \mathrm{ng} / \mathrm{ml}$ & - & - & - & - & 0.2 & - & 0.2 & 2 & 0.3 & 0.1 & $0.1-0.6$ & 21 & \\
\hline & & \multicolumn{4}{|c|}{$n=0$} & \multicolumn{4}{|c|}{$n=4(11 \%)$} & \multicolumn{4}{|c|}{$n=32(89 \%)$} & \\
\hline \multirow{3}{*}{ HT } & $\mathrm{T} 4 \mu \mathrm{g} / \mathrm{dl}$ & - & - & - & - & 10.1 & 2.1 & $8.3-13.6$ & 6 & 12 & & - & 1 & (10.5\%) \\
\hline & $\mathrm{T} 3 \mathrm{ng} / \mathrm{ml}$ & - & - & - & - & 1.9 & 0.3 & $1.7-2.3$ & 4 & 2.3 & & - & 1 & \\
\hline & & \multicolumn{4}{|c|}{$n=0$} & \multicolumn{4}{|c|}{$n=7(78 \%)$} & \multicolumn{4}{|c|}{$n=2(22 \%)$} & \\
\hline \multirow{6}{*}{$\mathbf{F P}$} & & $M$ & $S D$ & Range & $n$ & $M$ & $S D$ & Range & $n$ & $M$ & $S D$ & Range & $n$ & \multirow{6}{*}{$\begin{array}{c}41 \\
(47.5 \%)\end{array}$} \\
\hline & cbTSH $m U / I$ & 14 & 2.4 & $10-18$ & 32 & 24.8 & 5.4 & $20-34$ & 6 & 113.7 & 120.7 & $44-253$ & 3 & \\
\hline & sTSH mU/I & 4.0 & 1.6 & $1.4-8.3$ & 32 & 2.2 & 1.9 & $2.2-6.8$ & 6 & 3.5 & 2.1 & $2-4.9$ & 3 & \\
\hline & T4 $\mu \mathrm{g} / \mathrm{dl}$ & 12.5 & 1.1 & $11-15$ & 32 & 11.9 & 2.2 & $8.6-14$ & 5 & 10.8 & 13 & $8.6-13$ & 2 & \\
\hline & T3 ng/ml & 1.8 & 0.4 & $1.2-2.6$ & 32 & 2.2 & 0.3 & $1.7-2.4$ & 5 & 1.3 & 0.1 & $1.2-1.4$ & 2 & \\
\hline & & \multicolumn{4}{|c|}{$n=32(78 \%)$} & \multicolumn{4}{|c|}{$n=6(14,6 \%)$} & \multicolumn{4}{|c|}{$n=3(7.3 \%)$} & \\
\hline
\end{tabular}

TSH-based CH screening in the Nicaraguan circumstances. This is in agreement with other efficiency trials performed in other countries using cord-blood for screening. $[6,23]$.

Finally, the lapse between the birth date and the initiation of L-thyroxine treatment in $\mathrm{CH}$ positive children was lower than 15 days in 15\% of cases, $15-30$ days in $10 \%$ and above 30 days in $75 \%$ of children. The average start of treatment was $57 \pm 34$ days from birth, ranging from 10 to 120 days.

\section{Discussion}

Nicaragua is a developing country with a population of 6 million inhabitants and with one of the lowest per capita gross domestic income in America.[33] A regional screening program for $\mathrm{CH}$ was launched in 2005, as result of an international collaboration. In our knowledge, such a non-profit volunteering international initiative was unique. The program expanded from one to ten departments of the country (from a total of 17) in its ten years of existence. The number of neonates screened for $\mathrm{CH}$ increased approximately 15 -fold in this period. The program reached a mean coverage of $71 \%$ of babies born in the participating departments, evolving from the initial $55 \%$ to a maximum of $87 \%$. This is remarkable for a non-governmental program not benefitting from the logistic and economic support of a national health system. So far, in Latin America only countries with long-standing screening programs of more than 20 years of experience (Cuba, Costa Rica, Uruguay and Chile) have succeeded to reach coverage rates over 95\%.[5] 
One hundred and fifty-three children were detected as suspicious for $\mathrm{CH}$ (total positive children at screening) in 10 years. Of them 96 were retested (recall rate 68\%, this percentage of children retested in serum for $\mathrm{CH}$ confirmation does not consider children who died before serum confirmation test) and 80 were confirmed as $\mathrm{CH}$ positive while 16 were euthyroid. The rate of recall was low due to several factors: the lack of official institutionalization of the program, the fact that children who are slightly affected do not attend the reevaluation, probably due to the erroneous perception of absence of illness by their relatives. The family economic situation is also a factor that limits the affordability of the displacement for retesting.

The PPV of the program is $83 \%$ a figure close to those of the $\mathrm{CH}$ programs in Mexico (75\%)[25], Paraguay (87\%)[34] and Argentina (88\%)[35]. The FP was $16.7 \%$. We hypothesized that this efficient FP could be influenced by the relatively low recall rate achieved. Therefore, we analyzed whether the children that actually attended the call from the central laboratory to be retested could be biased towards the most severe cases, as judged by their high TSH levels in cord-blood. Indeed, we showed that the mean neonatal TSH of children who did not attend the call for retesting ("no-retested" babies) was significantly lower than the TSH of children retested (Fig. 3). This suggests that the relatives of the children with mild hypothyroidism did not observe any clinical sign and subsequently disregarded the recall.

The incidence of $\mathrm{CH}$, including congenital $\mathrm{HT}$, in Nicaragua is therefore estimated as 1 in 3,229 newborns. We must point out that this incidence does not take into account the samples identified as inadequate from the total of screened children (Table 1), this incidence being within the range of incidences reported in other Latin American countries, either using heel blood (1:3670 in Brazil[36]) or cord-blood screening (1:3616 in Cuba[4] to 1:2313 in Uruguay[37]) .

The incidence found may be influenced by two unavoidable factors: low return rate of babies for $\mathrm{CH}$ confirmation (incidence can only be calculated over confirmed cases, in serum) and the high rate of inadequate blood samples at initial years of the program. If we suppose that the incidence of $\mathrm{CH}$ is the same in the non-retested group than in the retested group, the total number of children with $\mathrm{CH}$ would have been 127 , resulting in a theoretical incidence of 1 in 2023 neonates. The wide variation of incidences through the region, as for the rest of the world, can be influenced by technical issues, but also by ethnic (genetic) backgrounds as well as by environmental conditions like iodine deficiency[2] . Another fact emerging for the audit of the Nicaraguan program is that most of the babies identified were severely hypothyroid as judged by their T4 levels at confirmation, according to the categorization of $\mathrm{CH}$ severity by the ESPE guidelines[30]. Nevertheless, the low T4 values could be the consequence of the excessive elapsed time between delivery and hormone retesting in serum. Both the low $\mathrm{CH}$ incidence found, and the high proportion of severely hypothyroid babies identified led to the hypothesis that 20 $\mathrm{mU} / \mathrm{l} \mathrm{TSH}$ could be a relatively high cut-off for the detection of babies with moderate hypothyroidism. However, a 4-year trial lowering the TSH cut-off to $10 \mathrm{mU} / \mathrm{l}$ did not improve the detection rate of patients, neither with $\mathrm{CH}$ nor with $\mathrm{HT}$, while it worsened the PPV from $83 \%$ to $62.5 \%$. Nevertheless, the fact that when using this cut-off only $28 \%$ of the children come to the hormone evaluation in plasma, does not allow to claim the inexistence of $\mathrm{HC}$ in the $72 \%$ lost for confirmation.

Taking into account that the PPV worsened, we suggest that the cut-off of $20 \mathrm{mU} / \mathrm{l}$ is the most efficient threshold for the cord-blood TSH-based $\mathrm{CH}$ screening Nicaraguan strategy. This is the most widely used cut-off in cord-blood based screening programs worldwide $[6,23,24,32]$. Our study indicates a possible limitation of using cord-blood (collected at birth) with respect to using heel-blood (collected after $24 \mathrm{~h}$ ) when attempting to increase the detection of moderate and mild cases of congenital hypothyroidism, since heel-blood based programs truly achieved such goal by lowering cut-offs from 20 to $10-12 \mathrm{mU} / \mathrm{TSH}$. $[2,36,38]$

Finally, the Nicaraguan screening program has some obvious limitations in its development and faces clear challenges for the future. The mean sample rejection rate in the Nicaraguan program is still high (5.9\%), reflecting the need of regular training of the personnel involved in sample collection[3]. Nevertheless, this challenge represents a straightforward opportunity to increase the coverage of the program in the future. The recall rate of positive children at screening is also low, although similar to those found in countries with poor socioeconomic status, deficient transport and health care infrastructures, and population living in rural and remote areas (43.1\%).[5] The lapse between the birth date and the initiation of L-thyroxine treatment in confirmed $\mathrm{CH}$ children was high compared to other Latin America countries.[39,40].

\section{Conclusions}

Performance of the Nicaraguan $\mathrm{CH}$ screening program is comparable to those in Latin America also using cord-blood sampling in terms of coverage, detection effectiveness and incidence. The future screening efforts should concentrate in expanding the coverage of the screening to the whole country since only the $18.1 \%$ of babies benefited from screening along the 10-year program's existence, increasing the recall rate of positive babies and reducing the lapse between diagnosis and treatment of $\mathrm{CH}$.

\section{Acknowledgements}

The authors acknowledge the funding of the Nicaraguan Screening Program by the following institutions and agencies from Spain: Universidad de Alcalá, Gobierno de la Comunidad de Madrid, Fundación Abbott and Agencia Española de Cooperación Internacional al Desarrollo (Ministerio de Asuntos Exteriores y Cooperación, Spain). They are grateful to the tutors of the collaboration agreement of the Universidad Nacional 
Autónoma de Nicaragua - León Prof. Elia Dina Galo and the Universidad Autónoma de Madrid Prof. Javier Regadera for his invaluable help. Also the Nicaraguan pediatricians Tania Corpeño, Yubanca Pineda, Natividad Nieto, Juan Ramos, Nelly Rivera, Liseth Mairena, Cristian José Berríos, Nieves Sánchez and the staff of "Labor and Delivery" from the HEODRA hospital, León and the-staff of the Laboratorio de Bioanálisis at UNANLeón for the collection and handling of samples. Authors are in debt with Drs. J. Miguel Rodríguez-Frade, Leonor Kremer and Mario Mellado from the Centro Nacional de Biotecnología-CSIC (Madrid, Spain) for the generous gift of the anti-TSH monoclonal antibodies and their valuable advice in the establishment of the ELISA of TSH in blood spots.

\section{Ethics Approval and Consent to Participate}

All procedures were in accordance with the ethical standards of the Ethical Committee for Biomedical Research of the Faculty of Medical Sciences of UNAN-León and with the Helsinki Declaration of 1975, as revised in 2004. Informed consent was obtained from mothers to take cord-blood to perform the early diagnosis screening.

\section{Authors' Contributions}

Fúnez A: Data collection analysis and interpretation, drafting the article, final approval of the version to be published.

Lara ME: Design of the work and data collection (responsible for diagnosis of congenital hypothyroidism).

Chévez AC: Data analysis (responsible for evaluation of the thyroid profile in serum).

Castellón EA: Design of study and data collection (coordinator of activities for the neonatal screening program for congenital hypothyroidism).

Perán S: Design of the study and critical revision of the article. Toro MJ: Design of the study, critical revision of the article.

Montoya E: Design of the study, technical optimization of screening procedure and critical revision of the article and final approval of the version to be published.

Moreno JC: Design of the study, analysis of data, writing of the article and final approval of the version to be published.

\section{Declaration of Conflicting Interests}

The author(s) declared no potential conflicts of interest with respect to the research, authorship, and/or publication of this article.

\section{References}

1. LaFranchi SH. Approach to the diagnosis and treatment of neonatal hypothyroidism. J Clin Endocrinol Metab. 2011;96(10):2959-2967. doi:10.1210/jc.2011-1175
2. Ford G, LaFranchi SH. Screening for congenital hypothyroidism: a worldwide view of strategies. Best Pract Res Clin Endocrinol Metab. 2014;28(2):175-187. doi:10.1016/j.beem.2013.05.008

3. Segni M. Disorders of the Thyroid Gland in Infancy, Childhood and Adolescence. Thyroid Disease Manager. http://www.thyroidmanager.org/chapter/disorders-of-thethyroid-gland-in-infancy-childhood-and-adolescence/. Published 2017. Accessed april 30, 2017.

4. Borrajo GJ. Newborn screening in Latin America at the beginning of the 21st century. J Inherit Metab Dis. 2007;30(4):466-481. doi:10.1007/s10545-007-0669-9

5. Therrell BL, Padilla CD, Loeber JG, et al. Current status of newborn screening worldwide: 2015. Semin Perinatol. 2015;39(3):171-187. doi:10.1053/j.semperi.2015.03.002

6. Marrero N, Frómeta A, Coto R, Villegas L. Medición de TSH, T4 y Phe en muestras de sangre del cordón umbilical en papel de filtro: impacto en el tamizaje neonatal. Biomedica. 2000;20(1):33-41. doi:10.7705/biomedica.v20i1.1045

7. de Céspedes C, Saborío M, Trejos R, Abarca G, Sánchez A, Rojas L. Evolution and innovations of the national neonatal and high risk screening program in Costa Rica. Rev Biol Trop. 2004;52(3):451-466.

8. Queiruga G, Queijo C, Lemes A, Machado M, Garlo P. Sistema nacional de pesquisa neonatal en Uruguay. Mem Inst Investig Cienc Salud. 2011;9(2):72-77.

9. Cornejo V, Raimann E, Cabello JF, et al. Past, present and future of newborn screening in Chile. J Inherit Metab Dis. 2010;33(3)(suppl 3):S301-S306. doi:10.1007/s10545010-9165-8

10. Ascurra M, Caballero E, Samudio M. Detección neonatal en el Paraguay. Brechas para su cobertura universal. Mem Inst Investig Cienc Salud. 2015;13(2):86-102. doi: 10.18004/ Mem.iics/1812-9528/2015.013(02)79-88

11. Bermúdez AJ, de los Ángeles Valera D, Robayo DB, Ascencio A, Ching RB. Desarrollo de la tamización neonatal en Colombia: espectrometría de masas en tándem. Pediatria (Napoli). 2015;48(2):47-54. doi:10.1016/j.rcpe.2015.07.006

12. Chiesa A, Prieto L, Mendez V, Papendieck P, Calcagno Mde L, Gruneiro-Papendieck L. Prevalence and etiology of congenital hypothyroidism detected through an Argentine neonatal screening program (1997-2010). Horm Res Paediatr. 2013;80(3):185-192. doi:10.1159/000354409

13. Rendón ME, Morales I, Huerta E, Silva A, Villas MA. Birth prevalence of congenital hypothyroidism in Mexico. Paediatr Perinat Epidemiol. 2008;22(5):478-485. doi:10.1111/j.1365-3016.2008.00955.x

14. Rossato N. Pesquisa neonatal obligatoria: reflexiones. Arch Argent Pediatr. 2009;107(3):193-194. 
15. Deladoey J, Ruel J, Giguere Y, Van Vliet G. Is the incidence of congenital hypothyroidism really increasing? A 20-year retrospective population-based study in Quebec. J Clin Endocrinol Metab. 2011;96(8):2422-2429. doi:10.1210/ jc.2011-1073

16. Harris KB, Pass KA. Increase in congenital hypothyroidism in New York State and in the United States. Mol Genet Metab. 2007;91(3):268-277. doi:10.1016/j.ymgme.2007.03.012

17. Hinton CF, Harris KB, Borgfeld L, et al. Trends in incidence rates of congenital hypothyroidism related to select demographic factors: data from the United States, California, Massachusetts, New York, and Texas. Pediatrics. 2010;125(suppl 2):S37-S47. doi:10.1542/peds.2009-1975D

18. Mitchell ML, Hsu HW, Sahai I, Massachusetts Pediatric Endocrine Work G. The increased incidence of congenital hypothyroidism: fact or fancy? Horumon To Rinsho. 2011;75(6):806-810. doi:10.1111/j.1365-2265.2011.04128.x

19. Olivieri A, Fazzini C, Medda E. Italian Study Group for Congenital $\mathrm{H}$. Multiple factors influencing the incidence of congenital hypothyroidism detected by neonatal screening. Horm Res Paediatr. 2015;83(2):8693. doi:10.1159/000369394

20. Wassner AJ, Brown RS. Congenital hypothyroidism: recent advances. Curr Opin Endocrinol Diabetes Obes. 2015;22(5):407-412. doi:10.1097/MED.0000000000000181

21. Treviño J, Calle A, Rodríguez-Frade JM, Mellado M, Lechuga LM. Surface plasmon resonance immunoassay analysis of pituitary hormones in urine and serum samples. Clin Chim Acta. 2009;403(1-2):56-62. doi:10.1016/j. cca.2009.01.015

22. De Bernal M, Caldas M, Bonilla R, Chamorro GA, Matallana A. Tamización para hipotiroidismo congénito en Cali y constitución de un centro piloto de referencia para la identificación temprana de la enfermedad. Colomb Med. 2003;34:42-46.

23. Manglik AK, Chatterjee N, Ghosh G. Umbilical cord blood TSH levels in term neonates: a screening tool for congenital hypothyroidism. Indian Pediatr. 2005;42(10):1029-1032.

24. Abduljabbar $\mathrm{M}, \mathrm{Al}$ Shahri $\mathrm{A}, \mathrm{Afifi} \mathrm{A}$. Is umbilical cord blood total thyroxin measurement effective in newborn screening for hypothyroidism? J Med Screen. 2009;16(3):119-123. doi:10.1258/jms.2009.009035

25. Vela-Amieva M, Gamboa-Cardiel S, Pérez-Andrade ME, Ortiz-Cortés J, González-Contreras CR, Ortega-Velázquez V. Epidemiología del hipotiroidismo congénito en México. Salud Publica Mex. 2004;46(2):141-148. doi:10.1590/S003636342004000200008

26. Djemli A, Van Vliet G, Belgoudi J, Lambert M, Delvin EE. Reference intervals for free thyroxine, total triiodothyronine, thyrotropin and thyroglobulin for Quebec newborns, children and teenagers. Clin Biochem. 2004;37(4):328330. doi:10.1016/j.clinbiochem.2003.12.006

27. Hübner U, Englisch C, Werkmann H, et al. Continuous age-dependent reference ranges for thyroid hormones in neonates, infants, children and adolescents established using the ADVIA Centaur Analyzer. Clin Chem Lab Med. 2002;40(10):1040-1047. doi:10.1515/CCLM.2002.182

28. Kapelari K, Kirchlechner C, Högler W, Schweitzer K, Virgolini I, Moncayo R. Pediatric reference intervals for thyroid hormone levels from birth to adulthood: a retrospective study. BMC Endocr Disord. 2008;8(1):15. doi:10.1186/1472-6823-8-15

29. Rastogi MV, LaFranchi SH. Congenital hypothyroidism. Orphanet J Rare Dis. 2010;5(1):17. doi:10.1186/1750-11725-17

30. Léger J, Olivieri A, Donaldson M, et al; ESPE-PES-SLEPJSPE-APEG-APPES-ISPAE; Congenital Hypothyroidism Consensus Conference Group. European Society for Paediatric Endocrinology consensus guidelines on screening, diagnosis, and management of congenital hypothyroidism. Horm Res Paediatr. 2014;81(2):80-103. doi:10.1159/000358198

31. Rose SR, Brown RS; American Academy of Pediatrics, American Thyroid Association. Update of newborn screening and therapy for congenital hypothyroidism. Pediatrics. 2006;117(6):2290-2303. doi:10.1542/peds.20060915

32. Buyukbebiz A. Newborn screening for congenital hypothyroidism. J Clin Res Pediatr Endocrinol. 2013;5(suppl 1):8.

33. Central Inteligence Agency. Nicaragua. Central Inteligence Agency. The World Fact Book. https://www.cia.gov/library/ publications/the-world-factbook/geos/nu.html. Published 2019. Accessed 15 March 2019.

34. Ascurra M, Rodríguez S, Valenzuela A, Blanco F, Ortiz L, Samudio M. Incidencia de hipotiroidismo congénito en 14 regiones sanitarias del Paraguay. Rev Soc Boliv Pediatr. 2011;50(1):51-56. doi:10.4067/S0370-41062011000400012

35. González VG, Santucci ZC, Pattin BJ, Apezteguía M, Borrajo BG. Programa de pesquisa neonatal de hipotiroidismo congénito de la provincia de Buenos Aires: 1.377. 455 niños evaluados en diez años de experiencia. Arch Pediatr Urug. 2009;80(1):43-50.

36. Botler J, Camacho LAB, Cruz MM. Cruz MMd. Phenylketonuria, congenital hypothyroidism and haemoglobinopathies: public health issues for a Brazilian newborn screening program. Cad Saude Publica. 2012;28(9):1623-1631. doi:10.1590/S0102311X2012000900002 
37. Queiruga G, Vázquez J, Garlo P, Franca K, Soria A, Pacheco A. Hipotiroidismo congénito, un tema vigente: ¿Qué pasa con prematuros y gemelares? Arch Pediatr Urug. 2013;84(4):281-284.

38. Corbetta C, Weber G, Cortinovis F, et al. A 7-year experience with low blood TSH cutoff levels for neonatal screening reveals an unsuspected frequency of congenital hypothyroidism (CH). Horumon To Rinsho. 2009;71(5):739745. doi:10.1111/j.1365-2265.2009.03568.x
39. Vela-Amieva M, Ibarra I, Rodríguez GA, et al. Optimización del tiempo de diagnóstico del hipotiroidismo congénito en el Estado de Tabasco, México. Salud en Tabasco. 2009;15(1):823.

40. Paredes G, Castro B, Lay S, Vila R. Programa de diagnóstico precoz de hipotiroidismo congénito en Contramaestre durante 12 años. Medisan (Santiago de Cuba). 2003;7(2):2226. 